\title{
Further Studies on Cocoa Yellow Mosaic Virus
}

\author{
By A. A. BRUNT* AND R. H. KENTEN \\ West African Cocoa Research Institute, Tafo, Ghana $\dagger$ \\ AND A. J. GIBBS and H. L. NIXON \\ Rothamsted Experimental Station, Harpenden, Hertfordshire
}

(Received 10 August 1964)

\begin{abstract}
SUMMARY
Cocoa yellow mosaic virus from Sierra Leone is readily transmitted by sap to many woody and herbaceous dicotyledonous plants. It is serologically related to wild cucumber mosaic virus and to turnip yellow mosaic virus, and has similar chemical and physical properties. It is stable when frozen or lyophilized, inactivated when kept for $10 \mathrm{~min}$. at $65^{\circ}$, and is precipitated without loss of infectivity in a half-saturated ammonium sulphate solution. The particles appear to be $25 \mathrm{~m} \mu$ across when mounted in neutral phosphotungstate, and $29 \mathrm{~m} \mu$ when shadowed. All preparations contained infective nucleoprotein particles which sedimented at $108 \mathrm{~S}$, and non-infective protein shells which sedimented at $49 \mathrm{~S}$.
\end{abstract}

\section{INTRODUCTION}

In 1958 cocoa plants with unusual symptoms were found in Sierra Leone, from which Blencowe, Brunt, Kenten \& Lovi (1963) obtained a virus apparently different from any virus previously recognized in cocoa in West Africa. In the present paper we report the results of further experiments with this virus, which we propose shall be called cocoa yellow mosaic virus (CYMV).

\section{METHODS}

A stock culture of CYMV from Giehun, Sierra Leone, was kept in graft-infected cocoa seedlings (Theobroma cacao L.) and in Chenopodium amaranticolor Coste $\&$ Reyn and C. quinoa Willd. seedlings infected originally by inoculation with cocoa leaf extracts.

The infectivity of different virus suspensions was compared by counting either the numbers of lesions that developed on the inoculated leaves of Chenopodium amaranticolor or the proportion of inoculated cocoa beans which later produced seedlings showing symptoms (after about 80 days). Cocoa beans were used in preference to cocoa seedlings, not only for convenience, but also because they showed symptoms sooner, usually on the first leaves produced. In the first experiments one cotyledon was removed from each bean before it was inoculated, but later whole beans were used because, as with cocoa swollen shoot virus (Brunt, Kenten \& Nixon, 1964), they were more susceptible: in nine tests a total of 149

* Present address: Glasshouse Crops Research Institute, Littlehampton, Sussex, England.

† Since renamed: Cocoa Research Station, Ghana Academy of Sciences, Tafo, Ghana. 
out of $197(75 \%)$ inoculated whole beans, but only 76 out of $192(40 \%)$ inoculated half beans, were infected. Cocoa beans and plants were inoculated by using a small hog's bristle brush (Reeve's no. 3) that had been dipped in inoculum; C. amaranticolor and other plants were inoculated by finger. An abrasive was usually added to the inocula : Celite 545 (Johns Manville Ltd.) for cocoa beans and hard-leaved plants and Hyflo Super Cell (Johns Manville Ltd.) or 600-mesh carborundum for other plants.

Some purified preparations of the virus were made from infected cocoa leaves. The leaves were mechanically macerated in twenty times their weight of water or a neutral buffer containing either $0.05 \mathrm{M}-\mathrm{Na}_{2} \mathrm{HPO}_{4}+0.005 \mathrm{M}$-diethydithiocarbamate (DIECA) or $0.05 \mathrm{M}-\mathrm{Na}_{2} \mathrm{HPO}_{4}+0.01 \mathrm{~m}$-thioglycollic acid $+0.005 \mathrm{~m}$-DIECA. The slurry was then filtered through muslin, and the resulting extract clarified by centrifugation for $20 \mathrm{~min}$. at $8000 \mathrm{~g}$. The virus was then either sedimented from the clarified extract by centrifugation at $75,000 \mathrm{~g}$ for $2 \mathrm{hr}$ or precipitated by halfsaturating the extract with ammonium sulphate and centrifuging at $8000 \mathrm{~g}$ for $20 \mathrm{~min}$. The pellet was then resuspended in $\frac{1}{50}$ th to $\frac{1}{200}$ th of the original volume of water, or neutral $0.03 \mathrm{M}$-phosphate, or in normal saline when used to inject rabbits. Other preparations of the virus were made from leaves of infected Chenopodium amaranticolor. Infected leaves were macerated mechanically in at least five times their weight of a solution containing $0.05 \mathrm{M}$-ascorbic acid $+0 \cdot 1 \mathrm{M}$-disodium hydrogen phosphate $(\mathrm{pH} \mathrm{7} \cdot 0)$. Chloroform (a quarter of the volume of buffer) was then added, and, after the mixture had been macerated further to form an emulsion, it was centrifuged at $8000 \mathrm{~g}$ for $10 \mathrm{~min}$. and the aqueous phase removed. The virus was then purified and concentrated from the aqueous extract by two or more cycles of differential centrifugation, with $0.03 \mathrm{M}$-phosphate $(\mathrm{pH} \mathrm{7.5)}$ as the suspending fluid. Finally the preparations were dialysed against $\mathbf{0 . 0 3} \mathbf{M}$-phosphate to remove traces of ascorbic acid. The other viruses used in the serological tests were purified in the same way.

Preparations were fractionated by centrifuging them in sucrose density gradients, and were examined in a Siemens Elmiskop I electron microscope by the methods described by Nixon \& Harrison (1959).

Antisera were prepared by injecting rabbits intravenously with partially purified virus preparations obtained from artificially infected cocoa seedlings by ultracentrifugation. The virus was injected into the rabbits either intravenously or intramuscularly, after being emulsified in an equal volume of Freund's complete adjuvant. The rabbits were bled about 10 days after the last injections. One rabbit produced a serum with a titre of $1 / 512$ after three intravenous injections at 3-day intervals, whereas another gave a titre of 1/1280 after one intravenous injection followed by two intramuscular injections at fortnightly intervals, with a final intravenous injection 1 week later. Serological tests were done by the tube precipitation method (Bawden, 1958).

\section{RESULTS}

\section{Host-range and symptoms}

The two plant species we found to be most useful for work with cocoa yellow mosaic virus (CYMV) were cocoa and Chenopodium amaranticolor. Blencowe et al. (1963) described the mosaic symptoms shown by infected cocoa (Pl. 1, fig. 2). 
C. amaranticolor was readily infected by inoculation with water extracts of infected cocoa or C. amaranticolor; numerous necrotic lesions developed on inoculated leaves 1-2 weeks after inoculation, and tip leaves produced later showed chlorotic and necrotic flecks and many were distorted (Pl. 1, fig. 3).

The susceptibility of other plant species to CYMV was tested. Most species were

Table 1. Hosts of cocoa yellow mosaic virus

(a) Species susceptible to CYMV (*those infected systemically)

\begin{tabular}{|c|c|}
\hline Apocynaceae & Vinca rosea L.* \\
\hline Begoniaceae & Begonia \\
\hline Bombacaceae & $\begin{array}{l}\text { Adansonia digitata L.*, Ceiba pentandra (L.) Gaertn.*, Pachira } \\
\text { oleagina Decne. }\end{array}$ \\
\hline Chenopodiaceae & $\begin{array}{l}\text { Beta vulgaris } L \text {. (sugar beet var. Klein E.) } \dagger, \text { Chenopodium } \\
\text { amaranticolor Coste \& Reyn.* }{ }^{+}, \text {C. quinoa Willd. } \ddagger\end{array}$ \\
\hline Cucurbitaceae & $\begin{array}{l}\text { Cucurbita ficifolia Bouche, C. melo-pepo L. (Delicious Golden), } \\
\text { C. pepo L. (Orange Gourd), Cucumis melo L. (Cantaloup } \\
\text { Charantais), C. sativus L. (Lockies Perfection, Tender and } \\
\text { True, Gherkin), Luffa cylindrica Roem., Momordica charantia L. }\end{array}$ \\
\hline Papillionaceae & Voandezia subterranea, Vigna sinensis L.† \\
\hline Solanaceae & $\begin{array}{l}\text { Nicotiana tabacum L. (White Burley), N. clevelandii Gray } \dagger \text {, } \\
\text { Nicandra physaloides L.* }\end{array}$ \\
\hline Sterculiaceae & $\begin{array}{l}\text { Abroma augusta L.*, Cola lateritia K. Schum. var. maclaudi } \\
\text { (A. Chev.) Brenan \& Keay*, Leptonychia pubescens Keay, } \\
\text { Sterculia foetida, Theobroma cacao L.*, T. bicolor Humb. \& } \\
\text { Bonpl.*, T. grandiflora K. Schum.*, T. speciosa Spreng* }\end{array}$ \\
\hline
\end{tabular}

(b) Species inoculated with CYMV, but which showed no symptoms, and from which CYMV was not recovered

\begin{abstract}
Amaranthaceae
Bombacaceae

Caesalpiniaceae

Compositae

Cucurbitaceae

Cruciferae

Euphorbiaceae

Gramineae
\end{abstract}

Musaceae

Nyctaginaceae

Papillionaceae

Polemoniaceae

Portulaccaceae

Solanaceae

Sterculraceae

Tiliaceae

Umbelliferae
Gomphrena globosa L. $\dagger$

Bombax brevicuspe Sprague

Caesalpinia pulcherrima Sw.

Calendula officinalis $\mathbf{L}$., Lactuca taraxifolia, Zinnia elegans Jacq.

Momordica foetida

Brassica chinensis L. $\neq$, Raphanus sativus L.

Ricinodendron heudelotii (Baille) Pierre ex Pax.

Avena sativa L. (var. Blenda) $\dagger$, Dactylis glomerata L. $\dagger$, Hordeum vulgare L. (var. Proctor) †, Lolium perenne L. (var. S22) , Zea mays $\mathrm{L}$.

Musa balbisiana L. $\dagger$

Boerhavia diffusa

Arachis hypogea L., Phaseolus lunatus L., P. vulgaris L. (Canadian Wonder Improved, Kentucky Wonder, Masterpiece, Prince + ), Pisum sativum L. (Laxton's Wonder Superb), Soja max†, Trifolium incarnatum L. $\dagger$

Phlox drummondii Hook

Montia perfoliata (Willd.) Howell. $\dagger$

Capsicum frutescens L. (Tabasco), Datura stramonium L., Lycopersicum esculentum Mill., Nicotiana glutinosa L., Petunia hybrida Villm.\$, Physalis floridana L.t, P. peruvia L., $\boldsymbol{P}$. pruinosa L., Solanum melongea L., S. verbascifolium

Cola gigantea A. Chev., Guazama ulmifolia Lam., Sterculia tragacantha Lindl.

Corchorus aestuans $\mathrm{L}$.

Daucus carota L. $\dagger$

All plants inoculated with CYMV from, and back tested to Theobroma cacao; except those marked $\dagger$, which were inoculated with partially purified CYMV and back tested to Chenopodium amaranticolor, and those marked $\$$, which were tested in both ways. 
inoculated with infective cocoa leaf extracts but some were inoculated with preparations of the virus purified from Chenopodium amaranticolor. All were tested for infection after about 1 month by inoculating sap from the leaves which had been inoculated and from the uninoculated tip leaves to either cocoa beans or C. amaranticolor. Table 1 shows that CYMV has many hosts, which include woody and herbaceous species of different dicotyledonous families. The failure to infect some species may have been caused by inhibitors of infection in the cocoa leaf extract or preparations from C. amaranticolor; however, some species known to be influenced by such inhibitors, including Cucumis and Nicotiana spp., were readily infected in these tests.

Properties of the virus

In these tests water extracts of the first flush leaves of cocoa seedlings, infected as beans, were used. Since cocoa leaf extracts are very mucilaginous, they were diluted to contain the equivalent of $1 \mathrm{~g}$. leaf in $20 \mathrm{ml}$. distilled water. Such diluted extracts were at about $\mathrm{pH} 6 \cdot 3$. Extracts were made only from leaves showing clear symptoms, for these were more infective than extracts of symptomless leaves or other parts of infected plants. Such extracts sometimes caused infection when diluted to $10^{-4}$ with water and inoculated with Celite (Table 2 ) which increased the infection end-point a thousand-fold.

Table 2. Thermal inactivation of cocoa yellow mosaic virus

\begin{tabular}{|c|c|c|c|c|c|c|}
\hline \multirow{3}{*}{$\begin{array}{c}\text { Dilution of } \\
\text { extract }\end{array}$} & \multicolumn{5}{|c|}{ Cocoa leaf extracts heated for $10 \mathrm{~min}$. at } & \multirow[b]{2}{*}{ Unheated } \\
\hline & $65^{\circ}$ & $60^{\circ}$ & $\mathbf{5 5}{ }^{\circ}$ & $50^{\circ}$ & $45^{\circ}$ & \\
\hline & \multicolumn{6}{|c|}{$\%$ infected beans (about 25 beans per treatment) } \\
\hline $1 / 1$ & $0^{*}$ & 5 & 25 & 80 & 67 & 74 \\
\hline $1 / 10$ & - & $\mathbf{0}$ & $\mathbf{3}$ & 41 & 63 & 87 \\
\hline $1 / 100$ & - & 0 & 0 & 3 & 23 & 30 \\
\hline $1 / 1000$ & - & $\mathbf{0}$ & $\mathbf{0}$ & 0 & $\mathbf{0}$ & $\boldsymbol{\gamma}$ \\
\hline
\end{tabular}

Stability at different temperatures. When $2 \mathrm{ml}$. samples of extracts were heated to different temperatures, some infectivity remained after $10 \mathrm{~min}$. at $60^{\circ}$, but not at $65^{\circ}$ (Table 2). At $25-30^{\circ}$ the extracts were infective after 16 days, but not after 32 days; at $0-4^{\circ}$ they were still infective after 76 days; other extracts containing $0 \cdot 2 \mathrm{M}$-phosphate buffer ( $\mathrm{pH} 8 \cdot 0$ ) were highly infective after 100 days at $0-4^{\circ}$. Infected cocoa leaves and water extracts of the leaves were frozen and thawed with no apparent effect on the infectivity of the virus they contained. Infectivity was also retained in cocoa leaves dried and stored over anhydrous alumina at $25^{\circ}$, and in lyophilized cocoa leaf extracts or Chenopodium amaranticolor sap.

Precipitation of the virus. CYMV precipitated from water extracts when these were half saturated with ammonium sulphate. Precipitates were suspended in distilled water, dialysed for $24 \mathrm{hr}$ against $0.003 \mathrm{M}$-phosphate $(\mathrm{pH} \mathrm{8.0)}$ ), and centrifuged briefly at $8000 \mathrm{~g}$ to sediment insoluble material. The resulting suspensions were almost colourless, slightly turbid, and contained most of the infectivity of the original extract. By contrast, when extracts of infected cocoa leaves were mixed with different amounts of ethanol or acetone in the cold to give concentrations of 
30-75\% and 25-60\% (v/v), respectively, the sparse precipitates which formed were not infective when resuspended in water.

The virus was not precipitated when extracts of infected cocoa leaves were adjusted to different $\mathrm{pH}$ values between $\mathrm{pH} 3$ and $\mathrm{pH} 6$, though infectivity was apparently destroyed when the extract was acidified to $\mathrm{pH} 3 \cdot 0$.

\section{Partially purified preparations}

Partially purified preparations made by differential centrifugation were slightly turbid and usually colourless or slightly yellow. The virus crystallized when ammonium sulphate was added slowly to these preparations as described by Markham \& Smith (1949) for crystallizing turnip yellow mosaic virus (TYMV); these crystals were similar to but smaller than those of TYMV. They were kept in the ammonium sulphate solution for 12 months at $4^{\circ}$, without increasing in size; they dissolved when the ammonium sulphate was removed by dialysis.

Electron microscopy. Extracts of infected cocoa or Chenopodium amaranticolor leaves contained many approximately spherical particles, not found in comparable preparations from uninfected plants. The particles appeared to be $25 \cdot 2 \mathrm{~m} \mu$ across when negatively stained (Pl. 1, fig. 5) and $29.0 \mathrm{~m} \mu$ when shadowcast after fixation with $2 \%(\mathrm{v} / \mathrm{v})$ formalin for $1 \mathrm{hr}$. The first figure is presumably an underestimate because stain penetrates into the particles, and the second an overestimate because the particles flatten on drying. The apparent size of negatively stained CYMV particles is almost the same as that recorded by Nixon \& Gibbs (1960) for similarly treated turnip yellow mosaic virus particles, but fixed and shadowed CYMV particles appear to be slightly larger than untreated shadowed TYMV at $26 \mathrm{~m} \mu$ (Cosentino, Paigen \& Steere, 1956). CYMV particles shadowcast without fixation with formalin always appear very flattened, unlike TYMV particles, which retain their shape well. Some of the particles in negatively stained preparations of CYMV seemed empty because they were penetrated by the phosphotungstate and were visible only as outlines (Pl. 1, fig. 4). Others were partly penetrated by the stain and were an intermediate grey tone on the plate (Pl. 1, fig. 5, near the upper edge).

In the best electron micrographs, particles were indistinguishable from those of turnip yellow mosaic virus (Huxley \& Zubay, 1960; Nixon \& Gibbs, 1960), and showed the same arrangement of morphological subunits.

Centrifugation. Purified CYMV preparations, suspended in neutral $0 \cdot 1 \mathrm{M}-\mathrm{KC}$, were examined in a Spinco Model E analytical centrifuge. All showed two boundaries, with sedimentation coefficients of $49 \mathrm{~S}$ and $108 \mathrm{~S}$ (corrected to infinite dilution in water at $20^{\circ}$ ), which we have called the top component and whole virus, respectively (Markham \& Smith, 1949). The top component absorbed much less ultraviolet (u.v.) radiation than the whole virus, and during preparation by differential centrifugation some of it was inevitably lost. When the virus in extracts from infected Chenopodium amaranticolor leaves was concentrated and purified by precipitation with ammonium sulphate and examined in the analytical centrifuge the area of the schlieren peak for the top component was about two-thirds of that from whole virus.

The two components were separated by centrifugation in sucrose density gradients. Electron microscopy showed that the whole virus fraction contained mostly intact virus particles, unpenetrated by phosphotungstate. It had the u.v.absorption spectrum of a nucleoprotein (Fig. 1), and was highly infective. By 
contrast, the top component contained mostly particles penetrated by phosphotungstate, had the u.v.-absorption spectrum of a protein (Fig. 1), and was only slightly infective. We have assumed that the few intact particles and slight infectivity of the top component was due to incomplete separation, and that apparently empty particles seen in the whole virus fraction were either due to incomplete separation or to damage during mounting for electron microscopy. The

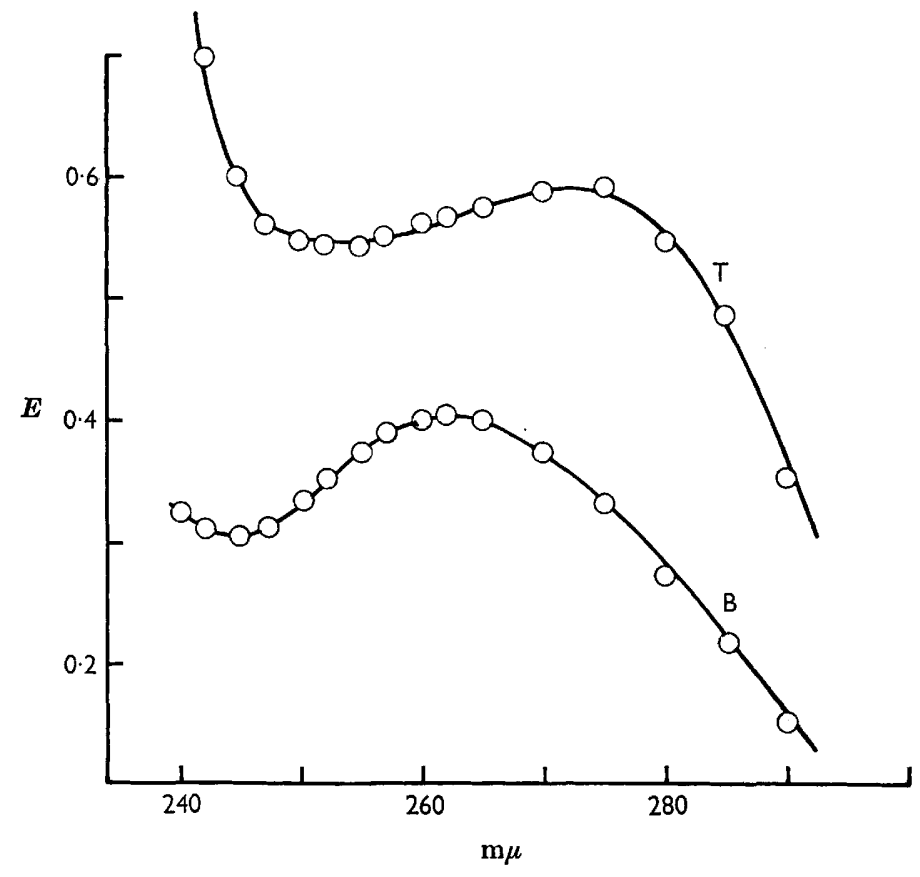

Fig. 1. Ultraviolet absorption spectra of separated cocoa yellow mosaic virus components. Upper line is spectrum of top component, lower line that of the bottom component (whole virus).

separated components each reacted with an antiserum made by injecting a rabbit with an unfractionated CYMV preparation. In gel diffusion tests each component gave only one line of precipitate, and in suitable tests these lines were confluent.

Thus CYMV preparations contain both fast sedimenting infective nucleoprotein particles and more slowly sedimenting non-infective protein particles, which have the shape and size of and are antigenically similar to the nucleoprotein particles.

Electrophoresis. CYMV preparations were dialysed against neutral $0.06 \mathrm{M}$ phosphate buffer and then examined in a Perkin-EImer Model 38 A electrophoresis. apparatus with a schlieren optical system.

All the preparations examined separated into two components, the major one migrating at $-11.8 \times 10^{-5} \mathrm{~cm} . / \mathrm{sec} . / \mathrm{V} . / \mathrm{cm}$. and the minor at $-11.3 \times 10^{-5} \mathrm{~cm} . /$ sec./V./cm. Because of the small difference in the mobilities of these electrophoretic components it was impossible to separate them and study their composition. They seem not to correspond to the protein and nucleoprotein components of the virus preparation, for in one experiment the separated whole virus contained both electro- 
phoretic components in the same relative amounts as in the unfractionated preparations.

Serology. Our results show that CYMV resembles turnip yellow mosaic (TYMV) and wild cucumber mosaic (WCMV) viruses in many respects. TYMV and WCMV are serologically related (MacLeod \& Markham, 1963), so tests were made to find whether CYMV is serologically related to them and to cowpea mosaic virus, which is also transmitted by beetles (Dale, 1949; Chant, 1959). Table 3 shows the sources of the viruses and antisera used in the tests.

Table 3. Hosts and sources of virus antigens

\begin{tabular}{|c|c|c|c|}
\hline Virus & $\begin{array}{l}\text { Host species for } \\
\text { virus for injection }\end{array}$ & $\begin{array}{l}\text { Host species for } \\
\text { virus used as antigen }\end{array}$ & Source \\
\hline Cocoa yellow mosaic & Theobroma cacao & Chenopodium amaranticolor & Sierra Leone \\
\hline Wild cucumber mosaic & Cucurbita pepo & C. pepo & MacLeod \& Markham \\
\hline Turnip yellow mosaic & Brassica chinensis & B. chinensis & Scotland \\
\hline Cowpea mosaic & & & \\
\hline Nigeria & Phaseolus vulgaris & P. vulgaris & Nigeria \\
\hline Trinidad & Phaseolus vulgaris & P. vulgaris & Trinidad \\
\hline Surinam & $?$ & - & Hari Agrawal \\
\hline
\end{tabular}

Table 4. Antiserum titrations

Antiserum titre (reciprocal of dilution end-point) after 4-hr incubation at $37^{\circ}$. In parentheses least dilution tested, when no reaction.

\begin{tabular}{|c|c|c|c|c|c|c|c|}
\hline \multirow[b]{3}{*}{ Antiserum } & \multirow{3}{*}{$\begin{array}{c}\text { Cocoa } \\
\text { yellow } \\
\text { mosaic } \\
\text { virus }\end{array}$} & \multirow{3}{*}{$\begin{array}{l}\text { Wild } \\
\text { cucumber } \\
\text { mosaic } \\
\text { virus }\end{array}$} & \multirow{3}{*}{$\begin{array}{c}\text { Turnip } \\
\text { yellow } \\
\text { mosaic } \\
\text { virus }\end{array}$} & \multicolumn{4}{|c|}{ Antigen } \\
\hline & & & & \multicolumn{2}{|c|}{ Cowpea mosaic virus } & \multicolumn{2}{|c|}{ Healthy sap } \\
\hline & & & & Nigeria & $\begin{array}{l}\text { Trini- } \\
\text { dad }\end{array}$ & $\begin{array}{l}\text { C. amar- } \\
\text { anticolor }\end{array}$ & $\begin{array}{c}P . \\
\text { vulgaris }\end{array}$ \\
\hline Cocoa yellow mosaic & 512 & $0(2)$ & $0(2)$ & $0(2)$ & - & $0(2)$ & - \\
\hline Wild cucumber mosaic & $8-16$ & 1024 & 16 & $0(2)$ & - & - & 一 \\
\hline $\begin{array}{l}\text { Turnip yellow mosaic } \\
\text { Cowpea mosaic }\end{array}$ & $0(2)$ & 8 & 1024 & $0(2)$ & 一 & - & - \\
\hline Nigerian & $0(1)$ & $0(2)$ & $0(2)$ & 64 & 64 & - & $0(2)$ \\
\hline Surinam & - & - & - & $0(16)$ & 128 & - & - \\
\hline
\end{tabular}

The serological relationships between the viruses were estimated by determining the precipitation end-points of the antisera when titrated against purified preparations of the different viruses. First the precipitation end-point of each virus preparation was found using the homologous antiserum, then the preparation was used as antigen in the antiserum titration tests at approximately four times the concentration at the precipitation end-points.

The tests (Table 4) confirmed the results of MacLeod \& Markham (1963) and showed r. distant serological relationship between TYMV and WCMV. The WCMV antiserum, but not the TYMV antiserum, precipitated CYMV, whereas the CYMV antiserum did not precipitate either TYMV or WCMV. The failure of CYMV antiserum to precipitate WCMV, when the reciprocal test was positive, may be because it had a lower titre than the WCMV antiserum.

Thus CYMV is apparently serologically related to WCMV but not to TYMV, even though TYMV and WCMV are related. However, further tests showed that WCMV has some antigenic groups common to both TYMV and CYMV, for when 
WCMV antiserum was mixed with excess CYMV it did not precipitate TYMV, and when mixed with excess TYMV it did not precipitate CYMV.

Neither CYMV, WCMV, TYMV nor their antisera gave precipitates in tests with the cowpea mosaic viruses or their sera. Limited tests showed that the different cowpea mosaic viruses were serologically related.

All the precipitates formed in these tests were white and granular, as usually obtained with isometric virus antigens, and unlike the less-dense microgranular and often coloured precipitates formed when plant proteins react with their antisera.

Dorner, Kahn \& Wildman (1958) and van Regenmortel (1963) found that the 'Fraction 1 ' proteins of different plant species were serologically related. Van Regenmortel (1963) has suggested that reactions with such proteins, which are often present in plant-virus preparations, might be responsible for the reports of distant serological relationships between viruses, such as those reported by MacLeod \& Markham (1963). However, our results confirm those of MacLeod \& Markham (1963) and provide further evidence to suggest that plant proteins are not responsible for the observed serological reactions. Dorner et al. (1958) and van Regenmortel (1963) apparently found one cross-reacting plant protein antigen in all species. However, our results (Tables 3, 4) show the presence of at least three distinct antigens; one in Phaseolus vulgaris only, one in both Brassica chinensis and Cucurbita pepo only, and another in C. pepo and Chenopodium amaranticolor only. Furthermore, the preparations of CYMV, WCMV, and TYMV used as antigens in our tests were highly purified and concentrated, and they were therefore diluted 1/32, 1/100, and 1/150 respectively for use in serological tests. The WCMV and TYMV preparations showed no components attributable to plant proteins when examined in the analytical centrifuge. By contrast, the cowpea mosaic preparation was relatively impure. It was diluted only to $1 / 10$ for serological tests, and contained more plant protein than the other virus preparations. Out of all those tested, it should therefore have been the most readily precipitated by antibodies to plant proteins, and yet it reacted only with its homologous antiserum. Dorner et al. (1958) found that the precipitation end-point of untreated tobacco sap was only 1/320 when tested in ring interface tests with an antiserum specifically prepared against 'Fraction 1' protein. Thus it is unlikely that enough plant protein to give a precipitate was present in the diluted antigen preparations we used except with cowpea mosaic virus preparations.

\section{DISCUSSION}

An interesting feature of cocoa yellow mosaic virus (CYMV) is its similarity to turnip yellow mosaic virus (TYMV) and wild cucumber mosaic virus (WCMV). Their particles have similar shape, size, external morphology, and sedimentation rates; moreover, MacLeod \& Markham (1963) and MacLeod (personal communication) found that the nucleoprotein particles of all three viruses contain similar amounts of nucleic acid, of similar composition (with $37-40 \%$ cytidylic acid). Therefore it is perhaps not surprising that these viruses are serologically related; however, the relationship is unusual in that WCMV antiserum reacted with both CYMV and TYMV, though there was no reaction between TYMV and CYMV antiserum or CYMV and TYMV antiserum.

The natural vector of CYMV in Sierra Leone is not known. Blencowe et al. (1963) 
failed to transmit the virus by three species of mealy-bug, and attempts in Sierra Leone to transmit the virus by soil and seed also failed; 60 pots of soil collected from around the roots of naturally infected cocoa plants were each sown with 5 cocoa beans, none became infected, and 150 beans from naturally infected cocoa plants all produced apparently healthy seedlings. However, the similarity of CYMV to TYMV and WCMV, both of which are transmitted by chrysomelid beetles, suggests that CYMV may also have a beetle vector.

Other viruses have been found to be beetle transmitted, including cowpea mosaic viruses in Trinidad (Dale, 1949) and in Nigeria (Chant, 1959). Our tests, and those of Shepherd (1963) and Agrawal \& Maat (1964) have shown that the two cowpea viruses are closely serologically related, but that they are apparently unrelated to CYMV, TYMV or WCMV. Cowpea mosaic virus also differs from CYMV in other ways, for although preparations of it have two components, like those in CYMV preparations, the particles appear different in the electron microscope (Chant, 1959) and do not show clearly defined subunits when mounted in phosphotungstate. Furthermore, bean pod mottle virus, which has recently been shown to be beetletransmitted (Ross, 1963; Walters, 1964) and is serologically closely related to cowpea mosaic virus (Shepherd, 1963), has a nucleic acid composition (Semancik \& Bancroft, 1964) quite different from that of CYMV.

\section{REFERENCES}

Agrawal, H. \& MAat, D. Z. (1964). Serological relationships among polyhedral plant viruses and production of high titred antisera. Nature, Lond. 202, 674.

Bawden, F. C. (1958). Reversible changes in strains of tobacco mosaic virus from leguminous plants. J. gen. Microbiol. 18, 751 .

Blencowe, J. W., Brunt, A. A., Kenten, R. H. \& Lovi, N. K. (1963). A new virus disease of cocoa in Sierra Leone. Tropical Agriculture, 40, 233.

Brunt, A. A., Kenten, R. H. \& Nixon, H. L. (1964). Some properties of cocoa swollen shoot virus. J. gen. Microbiol. 36, 303.

Chant, S. R. (1959). Viruses of Cowpea, Vigna unguiculata L. (Walp.) in Nigeria. Ann. appl. Biol. 47, 565.

Cosentino, V., Paigen, K. \& Steere, R. L. (1956). Electron microscopy of turnip yellow mosaic virus and the associated abnormal protein. Virology, 2, 139.

Dale, W. T. (1949). Observations on a virus disease of cowpea in Trinidad. Ann. appl. Biol. 36, 327.

Dorner, R. W., Kahn, A. \& Wildman, S. G. (1958). Proteins in green leaves. VIII. The distribution of 'Fraction 1 ' protein in the plant kingdom as detected by ultracentrifugal analyses. Biochim. biophys. Acta, 29, 240.

HuxuEY, H. E. \& ZubaY, G. (1960). The structure of the protein shell of turnip yellow mosaic virus. J. mol. Biol. $2,180$.

Macleod, R. \& Markham, R. (1963). Experimental evidence of a relationship between turnip yellow mosaic virus and wild cucumber mosaic virus. Virology, 19, 190.

Markham, R. \& Smith, K. M. (1949). Studies on the virus of turnip yellow mosaic. Parasitology, 39, 330.

Nixon, H. L. \& GrbBs, A. J. (1960). Electron microscope observations on the structure of turnip yellow mosaic virus. J. mol. Biol. 2, 197.

Nixon, H. L. \& Harrison, B. D. (1959). Electron microscopic evidence on the structure of tobacco rattle virus. J. gen. Microbiol. 21, 582.

Ross, J. P. (1963). Transmission of bean pod mottle virus in soybeans by beetles. Plant Dis. Reptr. 47, 1049.

Semancik, J. S. \& Bancroft, J. B. (1964). Further characterization of the nucleoprotein components of bean pod mottle virus. Virology, 22, 33 . 
SHEPHERD, R. J. (1963). Serological relationship between bean pod mottle virus and cowpea mosaic virus from Arkansas and Trinidad. Phytopathology, 53, 865.

Van Regenmortex, M. H. V. (1963). Serologically related plant contaminants in preparations of partly purified plant viruses. Virology, $21,657$.

WAlters, H. J. (1964). Transmission of bean pod mottle virus by bean leaf beetles. Phytopathology, 54, 240.

\section{EXPLANATION OF PLATE 1}

Fig. 1. Necrotic local lesions on leaf of Chenopodium amaranticolor inoculated with a purified cocoa yellow mosaic virus (CYMV) preparation.

Fig. 2. Tip leaf of C. amaranticolor plant systemically infected with CYMV, showing distortion and necrotic flecks.

Fig. 3. Chlorotic patterns on systemically infected leaf from a mechanically inoculated cocoa seedling.

Fig. 4. Electron micrographs showing empty protein particles of the top component of CYMV, separated from a purified preparation in a sucrose density gradient, and mounted in phosphotungstate; about $\times 240,000$.

Fig. 5. Nucleoprotein particles from the bottom component. Details as for fig. 4 .

Fig. 6. Schlieren pattern from a purified preparation of CYMV sedimenting in the analytical ultracentrifuge. Sedimentation is from left to right. 
Journal of General Microbiology, Vol. 38, No. 1

Plate 1
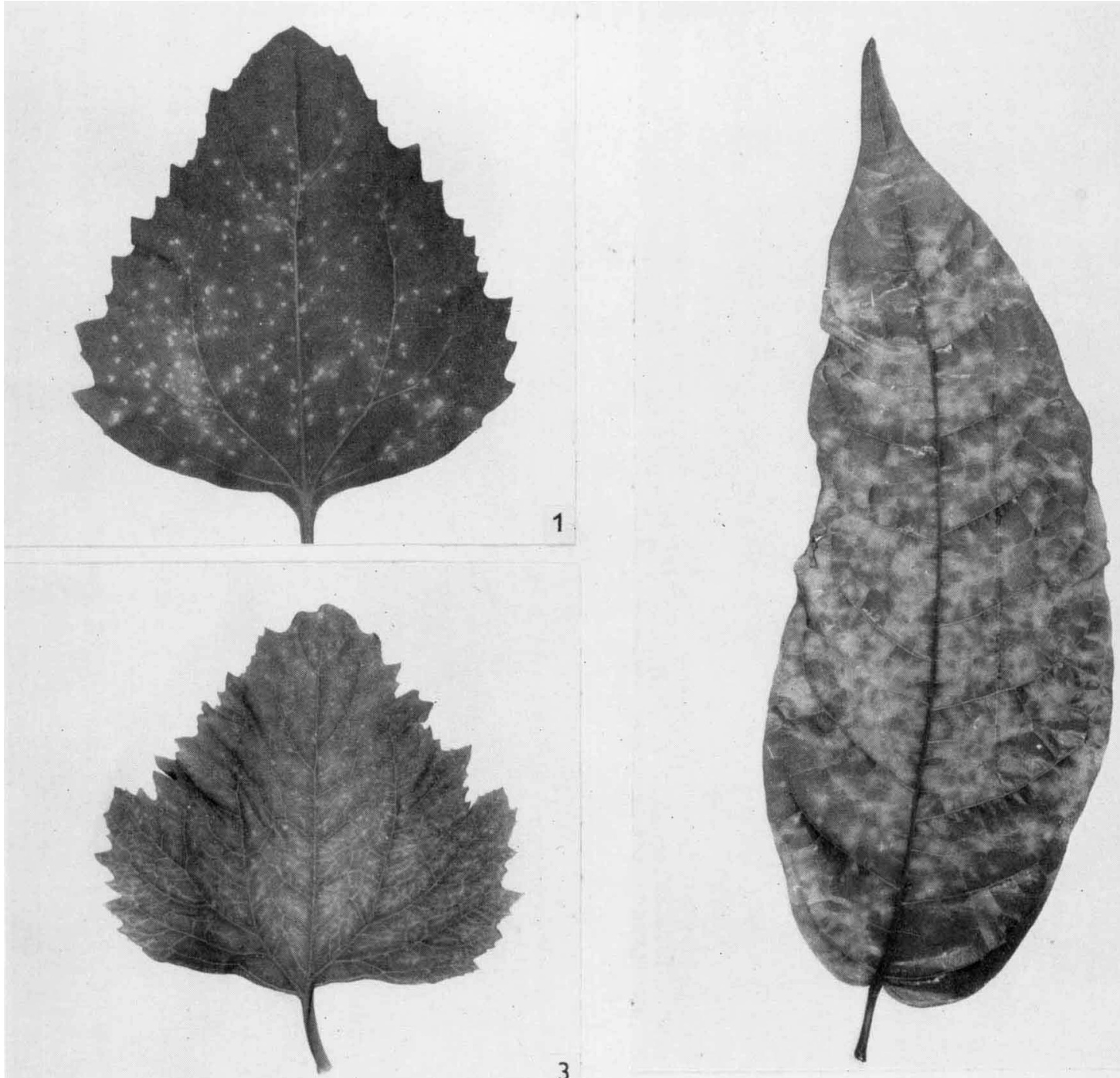

3
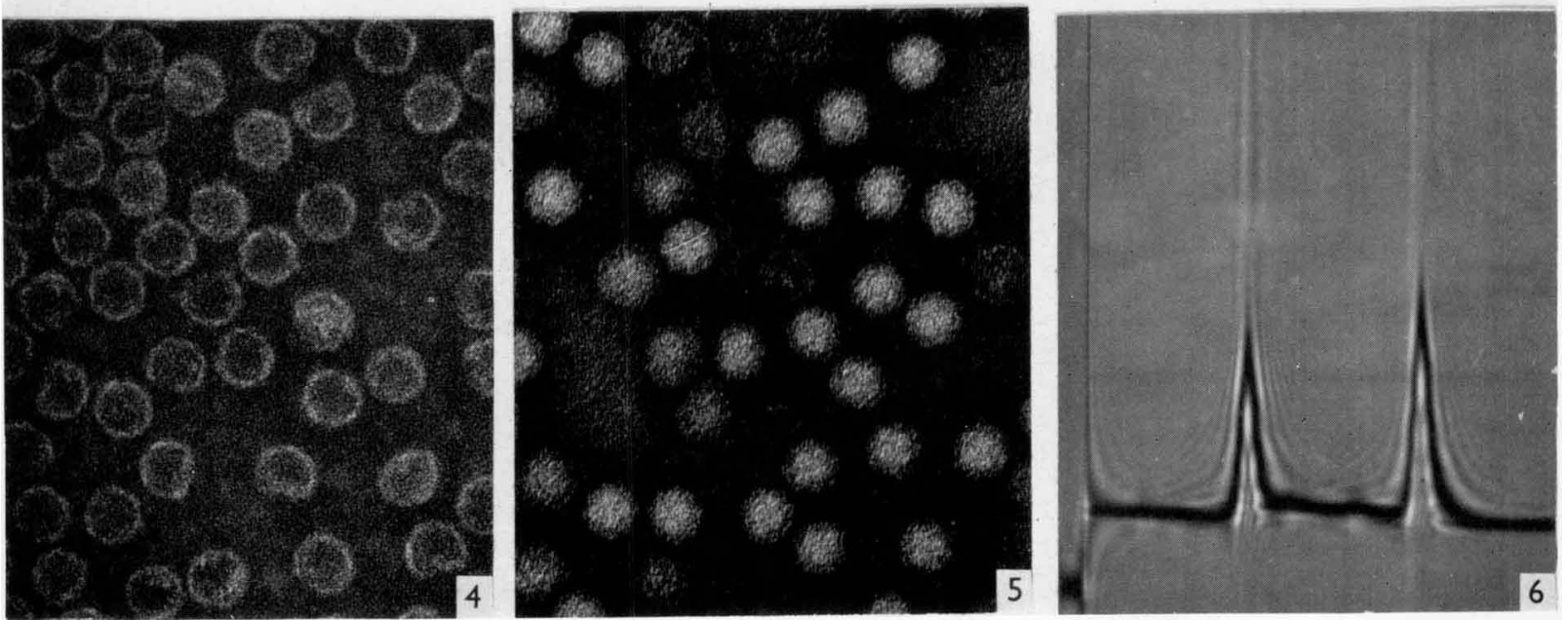

A. A. BRUNT AND OTHERS 
